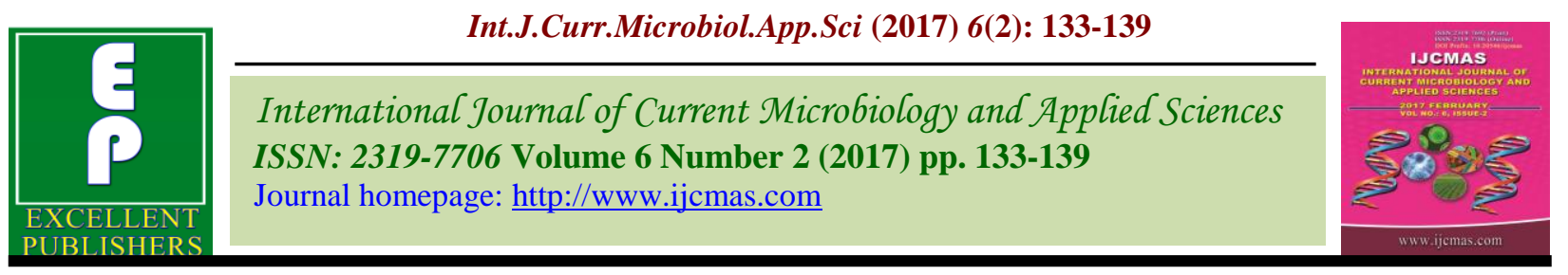

Original Research Article http://dx.doi.org/10.20546/ijcmas.2017.602.019

\title{
Enrichment of Soil Quality through Heterogeneous Mixture of Wastes by Eisenia fetida
}

\section{Sandeep Sirohi $^{1 *}$, Pankaj Kumar Tyagi ${ }^{1}$, Gyan Datta Tripathi ${ }^{1}$ and Suman Pal Singh Sirohi}

\author{
${ }^{1}$ Department of Biotechnology, MIET Meerut, Meerut- 250005, India \\ ${ }^{2}$ Department of Genetics and Plant Breeding, Kisan P.G College Simbhaoli, Hapur, India \\ *Corresponding author
}

\section{A B S T R A C T}

Keywords

Environment, Fertilizer, Reproduction, ppm, Eisenia fetida.

Article Info

Accepted:

12 January 2017

Available Online:

10 February 2017
Environment degradation is the major threat confronting the world and rampant use of chemical fertilizer contribute largely to the deterioration of the environment. Soil fertility highly affected due to imbalance use of fertilizers that has deep impact on productivity and soil degradation. This study gives an idea to identification of effects of variable diet on growth and reproduction of Eisenia fetida which leads to enhancement of soil quality. Various component of the soil like moisture content, $\mathrm{pH}$, sodium, potassium, nitrogen and total organic contents were $2.97 \%, 6,99.4 \mathrm{ppm}$, $16 \mathrm{ppm}, 1000 \mathrm{ppm}$ and $6.33 \%$ respectively, after 60 days.

\section{Introduction}

Modern agricultural practices like use of chemical fertilizers and some environmental problems like acid rain, pollution cause great reduction of soil fertility and essential nutrients for growth of plants as well as microbial flora and fauna of soil. It is possible to change in the nutritional content, enzymatic activities and other factors of soil by vermicomposting process. Vermicomposting refer to use of earthworm for composting of organic materials. Recently in biotechnology vermicompost is the product of vermicomposting which is an aerobic and bioxidative stabilization process of organic waste decomposition that use earthworms usually red wiggler white worms to create heterogeneous mixture and promote microbial activity in soil (Chattopadhyay, 2005). There is great possibilities of enrich the soil by Biofertilizer organisms. Natural breading and propagation of earthworms have been used for centuries as means of decomposing wastes and improving soil structure. It is more significant method for recycle and management of waste throughout the world. Eisenia fetida is a species of earthworm which can accelerate the mineralization rate and convert various materials into nutrients which are beneficial for soil fertility (Albanell et al., 1988).

Vermicomposting is the joint action of earthworm and microorganisms to decompose complex substrates by coordinated biological 
activity (Sim et al., 2010). Vermicompost is also called worm costing. It is the end product of breakdown of organic matter to earthworm. These costing contain reduce level of contaminants and a higher saturation of nutrients. Soil after vermicomposting having a good amount of nutrients that are usually absent in chemical fertilizers (Ansari et al., 2010). Vermicomosting not only as an alternative source of organic fertilizer but also provide economical significance like animals feed protein for the fish and poultry industries worldwide. They contain more available nutrient per weight than the organic waste from which they are produced (Cynthia et al., 2012). They contain nitrogen $(\mathrm{N})$, phosphorus $(\mathrm{P})$ and potassium $(\mathrm{K})$ content in the soil and are readily available for plant growth. The effects of vermicomposts on plants are not solely attributed to the quality of mineral nutrition is provided but also to its other growth regulating components such as plant growth hormones and humic acids. It is proved in various studies that vermicomposting is very effective from horticulture to medicinal and aromatic plant growth (Atiyeh et al., 1999; 2000; Anwar et al., 2005).

In India vermicomposting is being tested for treatment of agricultural, food and sugar industry wastes (Tripathiet al., 2014; Sirohi et al., 2014). They also included all the discarted solid materials from municipal, domestic, agricultural and industrial activities. There are various species may be use for vermicomposting like Eisenia foetida, Lampito mauritii, Bimasto parvus, Perionyx excavatus, Ocnerodrulus occidenalis, Dichogaster bolaui, Moniligaster perrieri.

\section{Materials and Methods}

Collection of Soil sample- Soil samples are collected from various places of Meerut (U.P.) and NCR region of India.

Collection of earthworms - Eisenia fetida species of earthworm is applied for present study of enrichment of soil as bioreactor organism.

Establishment of Colonies- Soil is speeded in five cardboard boxes and each up to 2 inch and $15 \mathrm{gm}$ of worm applied then again covered with soil as previous layer. Moisture maintained by sprinkle of water.

Preparation of earthworm nutrientsVarious domestic waste materials are provided as feed in each box.

Counting of earthworms- Amount of earthworm measured after 60 days.

\begin{tabular}{|c|c|c|c|}
\hline S.NO. & BOX & FEED & EARTHWORM \\
\hline 1 & Box 1 & Cow dung & +++ \\
\hline 2 & Box 2 & $\begin{array}{c}\text { Cow dung + Heterogeneous kitchen } \\
\text { products }\end{array}$ & +++ \\
\hline 3 & Box 3 & Heterogeneous kitchen products & +++ \\
\hline 4 & Box4 (Control) & Water only & +++ \\
\hline 5 & Box 5(Control) & All the above with water & nil \\
\hline
\end{tabular}

Analysis of soil - Soil sample from each box analyzed on various parameters like $\mathrm{pH}$, moisture content, organic content, sodium and potassium content, nitrate - nitrogen content and phosphorous content.

\section{Physical parameters}

Bulk density $\left(\mathrm{gm} / \mathrm{cm}^{3}\right)$ : The soils with high bulk density are inhibitive to root regeneration, low permeability and difficult 
filtration. The bulk density is inversely proportional to the space of soil. Air dried sample was kept in an oven at $110{ }^{\circ} \mathrm{C}$ until a constant weight attained, transferred a litter dried sample to a measuring cylinder and noted the volume and recorded the weight of this volume by using a balance.

Moisture content (\%): The moisture content in the soil was present in the form of precipitated water or through irrigation or drains through percolation, evaporation or uptake by plants. Air dried sample of soil was taken and weight. Air dried sample in oven at $110{ }^{0} \mathrm{C}$ was taken until constant weight was attained and cooled in a desiccators and recorded the final weight of sample.

Temperature $\left({ }^{0} \mathrm{C}\right)$ : Temperature is basically an important factor for biochemical reactions in the ecosystem. A rise in temperature of water accelerates chemical reactions, reduces solubility of gases, and amplifies the odor and texture which elevates metabolic activity of organisms.

\section{Chemical parameters}

pH (hydrogen ion concentration): 2 gm of air dried sample was taken to $20 \mathrm{ml}$ of distilled water. Suspension of $1: 10 \mathrm{~W} / \mathrm{V}$ dilution was shaken and left for 30 minutes. The $\mathrm{pH}$ of suspension was estimated by $\mathrm{pH}$ meter.

Nitrogen (ppm): 50 gm of air- dried sample was taken in a micro-Kjeldahl distillation flask and added $1 \mathrm{ml}$ of borax buffer solution. $5 \mathrm{ml}$ of boric acid indicator solution was added in a conical flask and placed it below the condenser, dipped in the contents of conical flask.

The Kjeldahl flask containing water sample was heated. Continued the distillation for 10 minutes after that $40 \mathrm{ml}$ of distillate was collected in a conical flask. The distillate in a conical flask was titrated against $0.01 \mathrm{~N}$ hydrochloric acid. Turning blue color to faint pink or brown indicator was end point. The blank was maintained with distilled water in a same way.

Phosphorous (ppm): 1gm of air dried sample was taken to which $200 \mathrm{ml}$ of sulphuric acid $(0.002 \mathrm{~N})$ was added. Suspension was taken and left for 30 minutes. The suspension was filtered through a filter paper (Whattman no.50). $25 \mathrm{ml}$ of filtrates was taken to the $1 \mathrm{ml}$ of ammonium molybdate and 3-4 drops of stannous chloric solution was added.

A blue color was appeared after 10 minutes recorded absorbance on spectrometer at 690 $\mathrm{nm}$. The blank was maintained with distilled water in the same way. The standard phosphate solution of different strengths, in similar manner was processed and calculated the concentration of standard phosphorous solution. Reduced the inorganic phosphorous content of sample by comparing its absorbance and noted the result in $\mathrm{MgPO}_{4}$.

Potassium (ppm): The soil extract as determination of calcium was prepared. The filters were placed on the flame photometer with a reading of $769 \mathrm{~nm}$ stared the compressor and the burner was lighted and the air pressure was kept at $51 \mathrm{lbs}$ and adjusted the gas feeder to have a blue sharp flame. Feed the standard potassium solution of the highest value in the range and adjusted the flame photometer to read full value of emission on the scale.

Organic matter (\% by wt): $0.5 \mathrm{~g}$ of air-dried sample was taken in $500 \mathrm{ml}$ flask which $10 \mathrm{ml}$ of potassium dichromate gradually $20 \mathrm{ml}$ of sulphuric acid was added, left for 30 minutes and then added with $200 \mathrm{ml}$ of distilled water, $10 \mathrm{ml}$ of phosphoric acid and $1 \mathrm{ml}$ of diphenyl amine indicator. The contents were titrated against ferrous ammonium sulphate solution. At the end point the dull green color changes to the brilliant green. 


\section{Results and Discussion}

Earthworms are important biological organism helping nature to maintain nutrient flow and minimize environmental degradation of soil quality. Earthworm eats most of the kitchen, fruit and vegetables wastes. In this study the effect of various diet prepared by wastes was observed on growth of Eisenia fetida which helpful in the enrichment of soil quality (Fig. 2). Kale et al., (1992) reported that various kind of organic wastes like agriculture wastes, kitchen wastes, some non degradable material like plastic etc can be vermicompost (Pattnaik et al., 2010).

All the parameter observed after a time interval of 30days and 60 days (Table 1). Moisture is an important parameter for growth of Eisenia fetida and observed maximum in box 1 which contains cow dung After 60 days which were increased double of 30 days and other boxes like box 2 also showed incensement of moisture contain significantly. For the growth of any organism $\mathrm{pH}$ is very important factor. There was maximum pH increased up to 6.5 in box 3 . Earlier Pandit and Maheshwari (2014) reported reduction in high $\mathrm{pH}$ of soil up to 7.21 by using sugarcane Bagasse as feed for Eisenia fetida.

Organic content was found maximum in box 3 after 60 days which was more than of 30 days but in box 2 organic content reduced in 60 days from 30 days.

Table.1 Various nutrients level after 30 days

\begin{tabular}{|c|c|c|c|c|c|c|c|c|c|c|c|}
\hline & & & & ter $30 \mathrm{~d}$ & & & & & er 60 & tys & \\
\hline S.No & Contents & Box 1 & Box 2 & Box 3 & Box 4 & Box 5 & Box 1 & Box 2 & Box 3 & Box 4 & Box 5 \\
\hline 1 & $\begin{array}{c}\text { Moisture } \\
\text { content }(\%)\end{array}$ & 1.914 & 1.177 & 1.237 & 1.510 & 2.439 & 3.138 & 2.987 & 1.821 & 1.329 & 1.789 \\
\hline 2 & pH & 6 & 5 & 6.5 & 5 & 5 & 6 & 5 & 6.5 & 5 & 5 \\
\hline 3 & $\begin{array}{c}\text { Organic } \\
\text { content } \\
(\%) \\
\end{array}$ & 0.209 & 0.835 & 0.623 & 0.416 & 0.420 & 3.8 & 6.33 & 0.886 & 0.831 & 0.835 \\
\hline 4 & $\begin{array}{c}\text { Sodium } \\
\text { content } \\
(\mathbf{p p m})\end{array}$ & 28 & 34.4 & 20 & 27 & 15 & 82 & 99.4 & 83.5 & 82.6 & 70.7 \\
\hline 5 & $\begin{array}{c}\text { Potassium } \\
\text { content } \\
(\text { ppm })\end{array}$ & 13.4 & 1.1 & 2.6 & 1.6 & 4 & 18.2 & 16 & 18.9 & 3.0 & 9.1 \\
\hline 6 & $\begin{array}{l}\text { Nitrogen } \\
\text { content } \\
(\mathrm{ppm}) \\
\end{array}$ & 450 & 500 & 300 & 275 & 250 & 875 & 1000 & 650 & 300 & 250 \\
\hline 7 & $\begin{array}{l}\text { Weight of } \\
\text { earthworm } \\
\text { (gm.) }\end{array}$ & $\begin{array}{l}\text { Initially } \\
\text { enrichm } \\
\text { to contr }\end{array}$ & $\begin{array}{l}15 \\
\text { ent anc } \\
\text { ol. }\end{array}$ & $\begin{array}{c}\text { of } \\
\text { o any } \epsilon\end{array}$ & $\begin{array}{l}\text { rms u } \\
\text { th wor }\end{array}$ & $\begin{array}{l}\text { ed for } \\
\text { added }\end{array}$ & 53 & 65 & 53 & 15 & 0 \\
\hline
\end{tabular}

*All the above data presented are in sum average of triplicate. 
Fig.1 The figure indicates comparatively increase of three main elements in soil in average of some total values

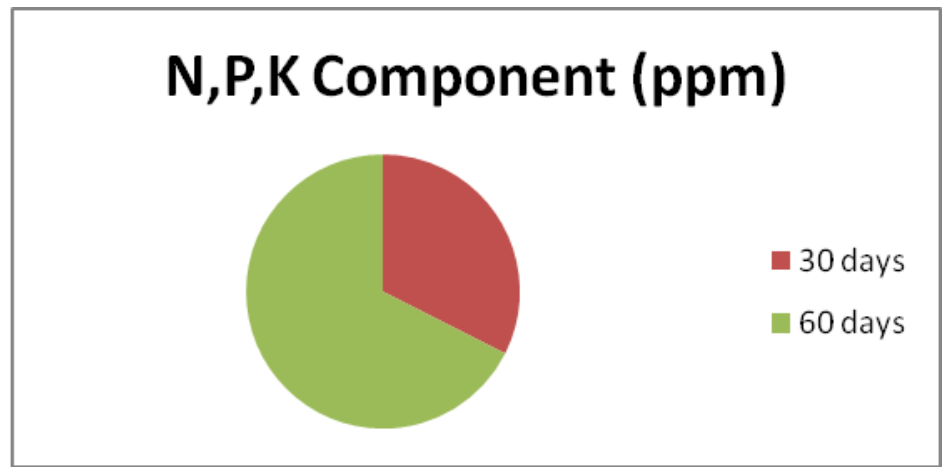

Fig.2 Picture during experiments design

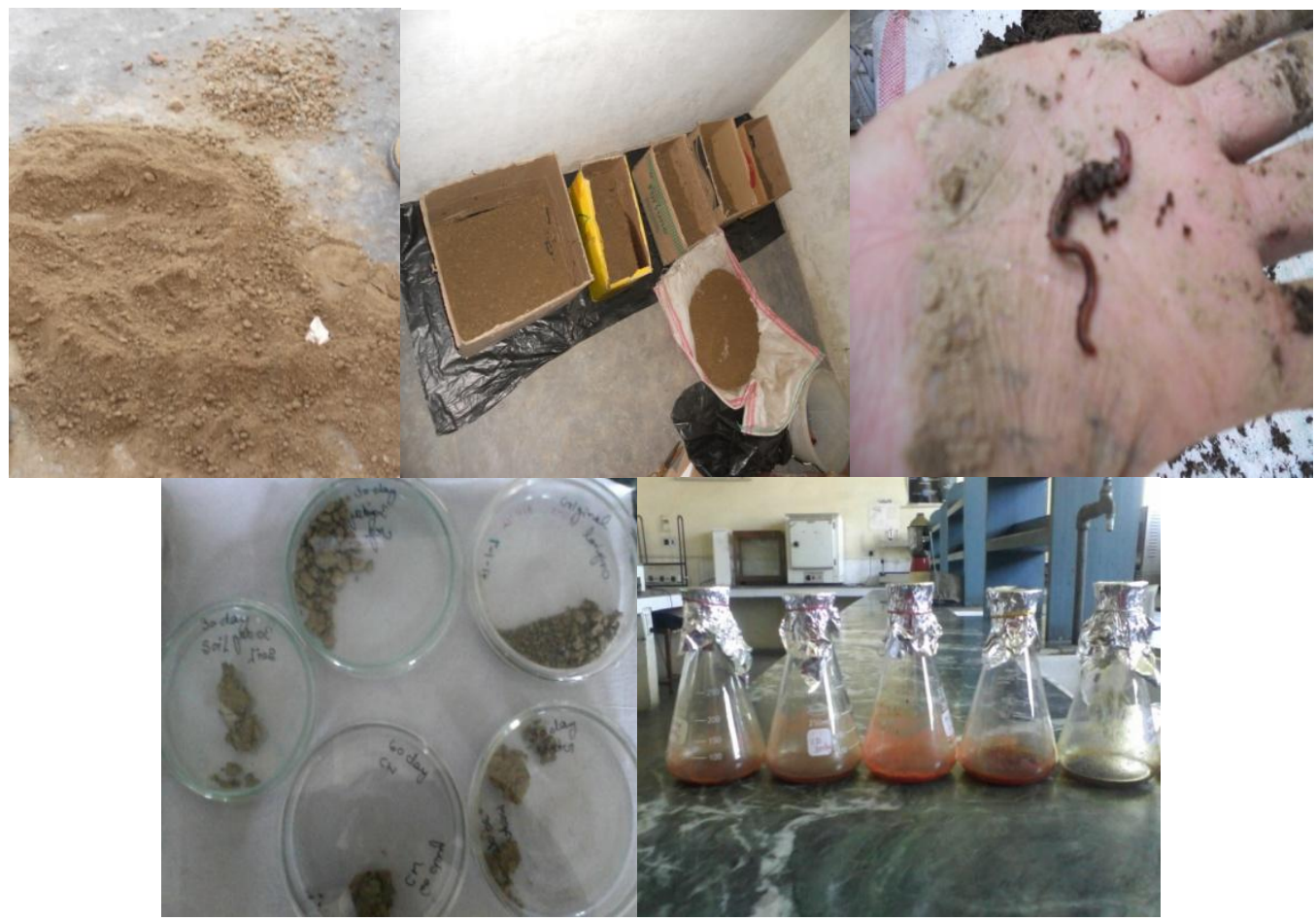

Sodium is an important essential nutrient which play vital role in various biochemical reaction and important for growth and development. Sodium content was increasing significantly and observed maximum in box 2 after 60 days.

Potassium and nitrogen are most important macronutrient and play vital role in all kind of life processes either any animal or plant and microorganisms. Level of these two macronutrients was also measured after 30 and 60 days respectively. Maximum potassium content was measured $18.9 \mathrm{ppm}$ in box 3 and maximum nitrogen was 1000 ppm, present in box 2. Khan and Ishak (2011) reported that vermicompost which is rich in various nutrients like potassium, Nitrogen, Sodium etc. is most significant for plants. After incubation of 60 days it was found that the population of Eisenia fetida much more increase which was measured in weight. Best 
possible diet of the growth of Eisenia fetida was present in box 2 which contains cow dung in addition with various heterogeneous kitchen waste materials. The population was initially incubated in each box contain 15 gm during start of process and after 60 days in box 2 it was measured 65 gm. Cynthia and Rajeshkumar showed a sustainable utility of vermicomposting process for sugar mill effluent treatment

In conclusion, it was observed that effect of various diets quit helpful for the growth of earthworm and maximum on box no. 3 . It is highly beneficial for increase of nutrients in the soil which lost due to various human made practices. A large amount of increase is observed in the vermicompost in comparison to original soil and two controls (Box no. 4 and 5). Moisture content, $\mathrm{pH}$, sodium, potassium, total organic content and nitrogen in vermicompost is $2.987 \%, 6,99.4$ ppm,16ppm, 6.33\%, 1000ppm respectively (Fig.1), whereas moisture content, $\mathrm{pH}$, sodium, potassium, total organic content and nitrogen in original soil [1.215\%, 6, 32.8ppm, 9ppm, 0\%, 250ppm], control 1 (box no. 4) [1.329\%, 5, 82.6ppm, 3ppm, 831\%, 300ppm] and control 2(box no. 5)[1.789\%, 5, 70.7ppm, $9.1 \mathrm{ppm} 835 \%, 250 \mathrm{ppm}]$. It is also a cost effective west disposal method which used to enrichment of soil. There is more expectations from the research to improve and enrich soil by such practices which is need of future.

\section{References}

Albanell, E., J. Plaixats, T. Carbrero. 1988. Chemical changes during vermicomposting (Eisinia fetida) of sheep manure mixed with cotton industrial waste, Biol. Fertility of soil, 6; 98-104

Ansari, A.A., S. Jaikishun. 2010. An investigation into the vermicomposting of sugarcane bagasse and rice straw and its subsequent utilization in cultivation of Phaseolus vulgaris $L$. in Guyana American-Eurasian J. Agri. Environ. Sci., 8(6), 666-671.

Anwar, M., D.D. Patra, S. Chand, Kumar, A.A. Naqvi, and S.P.S. Khanuja, 2005. Effect of organic manure and inorganic fertilizers on growth, herb, oil yield, nutrient accumulation and oil quality of French basil (Ocimum basilcum L.), Communications in Soil Sci. Plant Analysis, 36(14), 1737-1746.

Atiyeh, R.M., S. Subler, C.A. Edwards and, J. Metzger. 1999. Growth of tomato plants in Herticulture poting media amended with vermicomposts. Pedobiologia, 43: 724-728.

Atiyeh, R.M., S. Subler, C.A. Edwards, G. Bachman, J.D. Metzger, and W. Shuster. 2000. Effects of vermicomposts and composts on plant growth in horticulture container media and soil Pedobiologia, 44, 579-590.

Chattopadhyay, G.N. 2005. Vermicomposting as a biotechnological tool for recycling organic westes. In: Ghosh TK, Chakrabarti T, Tripathi G (eds) Biotechnol. Environ. Management, A.P.H. Publishing Corporation, New Delhi, vol 1pp 135-145.

Chattopadhyay, G.N. 2012. Use of vermicomposting biotechnology for recycling organic wastes in agriculture Int. J. Recycling of Organic Waste in Agri., 1: 8.

Cynthia, J.M. and K.T. Rajeshkumar. 2012. A study on sustainable utility of sugar mill effluent to vermicompost, Adv. Appl. Sci. Res., 3(2): 1092-1097.

Kale, R.D., B.C. Mallesh, K. Bano and D.J. Bagyaraj. 1992. Influence of vermicompost application on the available macronutrients and selected microbial populations in a paddy field. Soil Biol. Biochem., 24(13): 17-20. 
Khan, A. and F. Ishaq. 2011. Chemical nutrient analysis of different composts (Vermicomposts and Pitcomposts) and their effect on growth of a vegitative crop Pisum sativum, Asian J. Plant Sci. Res., 1: 116-130.

Norman, Q., Arancon and Clive, A. Edwards. 2005. Effects Of Vermicomposts On Plant Growth Paper presented during the International Symposium Workshop on Vermi Technologies for Developing Countries (ISWVT 2005), Los Banos, Philippines.

Pandit, N.P. and S.K. Maheshwaria. 2013. Vermi remediation of sugarcane byproducts into nutrient rich vermicompost through enhancing the bioconversion efficiency of Eisenia fetida by developing vermireactors, The J. Bioprocess Technol., Photon 99: 327337.

Pattnaik, S. and M.V. Reddy. Nutrient Status of Vermicompost of Urban GreenWaste Processed by Three Earthworm Species-Eisenia fetida, Eudrilus eugeniae, and Perionyx excavates, Appl. Environ. soil Sci., Pp.1-13.
Prabha, M.L., I.A. Jayraay, R. Jayraay, and D.S. Rao. 2007. Effect of vermicompost and compost on growth parameters of selected vegetable and medicinal plants, Asian J. Microbiol. Biotechnol. Environ. Sci., 9(2): 321-326.

Sim, E.Y.S. and T.Y. Wu, 2010. The potential reuse of biodegradable municipal solid wastes (MSW) as feedstocks in vermicomposting, J. Sci. Food and Agri., 90(13): 2153-2162.

Sirohi, S., S.P.S. Sirohi and P.K. Tyagi. 2014. Impact of industrial effluents on water quality of Kali river in different locations if Meerut, India J. Engi. Technol. Res., 6(4): 43-47.

Tripathi, G.D., Z. Javed, S. Sirohi and P.K. Tyagi. 2014. A Biotechnological Approach for Treatment of Sugar Industry Effluents: A Review Asian J. Chem. Pharmaceutical Res., 3(4): 1-5.

Watanabe, F.S. and S.R. Olsen. 1965. test of an ascorbic acid method for determining phosphorusin water and $\mathrm{NaHCO}_{3}$ extract from soil. Soil Sci. Society of America Proceedings, 29(6): 677-678.

\section{How to cite this article:}

Sandeep Sirohi, Pankaj Kumar Tyagi, Gyan Datta Tripathi and Suman Pal Singh Sirohi. 2017. Enrichment of Soil Quality through Heterogeneous Mixture of Wastes by Eisenia fetida. Int.J.Curr.Microbiol.App.Sci. 6(2): 133-139. doi: http://dx.doi.org/10.20546/ijcmas.2017.602.019 